\title{
MEDIA EXPOSURE BEHAVIOR ON POLITICAL ISSUES AND DEMOCRATIC POLITICAL ATTITUDE OF UNIVERSITY STUDENTS
}

\author{
Veerapon Vongprasert
}

Suan Sunandha Rajabhat University, Bangkok, Thailand

Education is one of the main institutions for students' development, while the latter is essential for the whole country's political, social, cultural and economic development. Political development has its objective dimension, that is political regime, and it also has a subjective dimension which covers, inter alia, political socialization in universities. The latter could be an important tool for building democratic political attitude among students.

This research is aimed at studying the factors affecting democratic political attitude by analyzing the mass media in 3 categories: newspaper, television and radio. It considers the behavior of media exposure on political issues of university students in the context of 5 variables: sex, age, field study, academic level, and birth place.

The sample group for this study consists of the students from Suan Sunandha Rajabhat University, College of Innovation and Management. The total number of respondents in the group is 126. The multi-stage random sampling was followed by the questionnaire used as a tool for data collection.

Keywords: democratic political attitude; political socialization; media exposure; university students.

\section{Introduction}

Globalization always has been and remains to be a potent force in the spread of democratic values and practices. Globalization also contributes to weakening the power of centralized governments and helps to empower citizens by fostering economic prosperity, acquisition of private property, and increased access to information. Globalization is often viewed as depriving democratically elected governments of their ability to determine public policies or to regulate the consequences of global decisions on the people who elected them (Payne, 2009).

Nowadays, Thai society becomes aware of political rights as such. In terms of political participation this suggests certain circulation of opinions and political thoughts, views and beliefs. Public opinion is the attitude of general public to a particular matter, the influencing opinion of people regarding public policies or a more or less broad consensus of opinions about the policies which should be pursued by state authorities. Attitude research plays an important role in understanding how these opinions are formed, changed, and measured

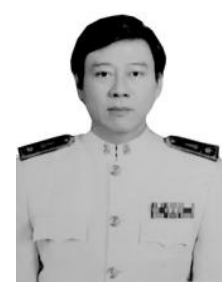

Veerapon Vongprasert

Bachelor of Economics Chulalongkorn University, Bachelor of Arts (Political Science), Ramkhamhaeng University., Master of Arts in Economics Chulalongkorn University, - Master of Political Science (Administration), Thammasat University, Bangkok, Thailand

Member of College of Innovation Management, Suan Sunandha Rajabhat Universirty, Bangkok, Thailand/ Research interests include political behavior, social and cultural factors of political preferences development, mass media in political behavior regulation

E-mail: veerapon.vo@ssru.ac.th 
(Mills, 2000). In this context, media exposure makes people share another person's feelings and emotions as if they are public thoughts. Political communication could wake up the brain so that it starts demanding the satisfaction of certain political needs, thus contributing to the transition from traditional society to modernizing society. The question is what has led to this rather precarious situation with public opinion in Thailand? Some may attribute it to the absence of good leadership while other may blame the lack of a democratic political culture in the country.

\section{Objectives}

This research aims to study the factors which affect democratic political attitude through analyzing media exposure in 3 categories: newspapers, television and radio. It considers the behavior of media exposure on political issues among university students in the light of 5 demographic variables: sex, age, field of study, academic level, and birth place.

The research thus studies the relationship between the behavior as to media exposure on political issues and the democratic political attitude among university students in Thailand.

\section{Literature review}

The research review can be summarized in 2 parts: democratic political attitude and role of media in politics.

\section{Democratic political attitude}

Democracy can be defined as a political power exercised either directly, or indirectly through participation, competition and liberty (O'Neil, 2015). Political attitude describes views regarding the necessary pace and scope of change in the balance between freedom and equality. This attitude is typically broken up into the categories of radical, liberal, conservative, and reactionary democracy.

Traditionally researchers note that all these attitudes are based on cognitive, affective, and behavioral information. Democracy as a notion, generally speaking, is derived from the Greek words "demos" (meaning people or populace) and "kratis" (stands for rule).

A political system consists of the system as such and the people who run this system. The human element in this research on university students is most important here. Democracy is not only a lip service to the idea that is critical in terms of opinions and attitudes - people are actually supposed to do something to support it. Practitioners in this rather specific field have to possess democratic beliefs, attitudes and culture.

The concept of political socialization shall be defined restrictively as it covers the development processes through which persons acquire political orientations and patterns. Political culture is a subjective psychological phenomenon that appears in the process of interaction between individuals and the political system.

The idea of political culture is essentially based on the idea that differences in societal institutions (norms and values) shape the political landscape. Political culture may also predetermine the preference for certain kinds of policies as well as a particular relationship between freedom and equality in the society. The behavioral revolution in political science was strongly connected to the modernization theory, which posited that as societies become 


\section{MEDIA EXPOSURE BEHAVIOR ON POLITICAL}

more modern, they would inevitably become also more democratic. Modernization is associated with better education, weakening of older traditional institutions that stressed authority and hierarchy, greater gender equality, and the rise of the middle class. To sum up, the modernization theory suggests that as societies become better educated and more economically sophisticated, they need and desire greater control over the state to achieve and defend their own interests (O’Neil, 2015).

The meaning of belief in this particular context could be summarized as 2 items:

First, conviction or acceptance that certain things are true or real;

Second, complete, unquestioning acceptance of something even in the absence of proof and especially if something is not supported by rational reasoning.

Political participation entails communicating with the elected officials and other related person regarding government expressing its viewpoints and demanding certain actions or public policies from the government. Vehicles for political participation include political parties, interest groups, and also free press. Political participation can be either conventional, or unconventional. Conventional participation includes voting, running for office, assisting with political campaigns, writing to elected officials, writing letters to newspapers about particular issues, and joining an interest group to influence public policies. Unconventional participation includes protests, mass demonstrations, civil disobedience campaigns, and sometimes even acts of violence (Payne, 2009).

Education is vitally important in this context since it is one of the most universal approaches to reaching international understanding and coooperation. Education plays a dual role in this sphere: it is reproducing certain aspects of the society and it is also preparing students to transform this society into its future form. The role of education in building the society is to help students to determine what is best to conserve in their cultural, economic and natural heritage and also what values and strategies should be nurtured more for attaining sustainability in local communities while contributing at the same time to national and global goals (Siribanpitak, 2009). The same author also pointed out that the educational approach human resources' development could be viewed from three positions.

First, education is one of the most important social activities since it is transmitting essential knowledge to students. As it was stated centuries ago by Plato, knowledge comes from outside the students' experiences and students learn only what previous generations learned.

Second, learning entails reconstruction. Students are actively involved in learning, thus, they are constantly reconstructing and reorganizing experience to gain better understanding of life as it is happening (John Dewey).

Third, reconstruction of the society overall should be the key purpose of all schools' functioning. Schools should criticize, change, and improve society (George Counts).

Democracy provides people with the opportunity to be active citizens rather than passive subjects. Human behavior is prescribed by knowledge and information. Education is supposed to enlighten university students so that they become less affected by politicians' manipulations.

Education produces human resources having or doing what is worthy and most desirable for the society because it is useful, necessary, or popular. A democratic political culture may be hard to develop within an authoritarian culture because democratic spirits are hindered by the habits and beliefs of the culture that is difficult to change or remove. 
Democratic political culture is a product of political socialization passing through basic socialization, political socialization process, political recruitment process (Pye, 1963). Democratic political attitude with its response by political stimuli leads to the formation of a political personality. Democratic political attitude supports democratic regime so that the latter can become more sustainable in the long term and thus - be more valued and honored by the people.

The core elements of democratic political culture as well as the measuring factors that affect democratic political attitude are as follows:

(1) Having trust and faith in democratic political regime;

(2) Having respect in humanity and each other;

(3) Realization of own responsibility as a civic citizen;

(4) Having the courage to give own opinion and comment on the events and attitudes with reasonableness and creativity;

(5) Participate in political activities, admiting the rule of democratic regime at the same time;

(6) Conceding there are other, different opinions;

(7) Entrusting the authority with reasonableness and legitimacy.

\section{Role of media in politics}

The important challenge in this regard is the information age and Thailand 4.0 development strategic plan. The world is getting much smaller through innovations and discoveries employing new technologies (Mills, 2000). The knowledge of new economic and social era are changing the society in which information expands rapidly around the globe. Money and capital flows are following new investment opportunities; organizations continually restructure themselves; government policies undergo volatile shifts as electorates become more and more important contributors. Therefore, politics in the fields of education and teaching under the conditions of knowledge society must develop so that to contribute to the improvement of individuals' capacities of taking risks, dealing with constant change, and undertaking inquiries when new demands and novel problems confront them (Hargreaves, 2003).

Meanwhile, persuasion is the process of changing or reinforcing attitudes, beliefs, or behavior. For example, while watching a television debate between two politicians, viewers would listen to both sides and make their minds up basing on the discussion of issues and the quality of evidence. But if the viewers are in the mindless mode (for example, watching not attentively while entertaining friends), they would rely on simple cues only. Typically, the cues that influence us most in the situations like this are the attractiveness of speakers, the reactions of friends, and the pleasure while agreeing with their arguments (Mills, 2000).

Higher education is now facing another major challenge brought about by the liberalization of trade and investment. The liberalization of trade when it comes to education services and personnel are both within and across the region. The impact of higher education development on producing high-quality human resources for a country would help keeping up with the challenges brought about by globalization. In the process of teaching, a special kind of trust is required on the side of university students. Teaching in the knowledge society also needs to show political courage and integrity by reconnecting the agenda for educational improvements with the agenda of social development (Hargreaves, 2003). 


\section{MEDIA EXPOSURE BEHAVIOR ON POLITICAL}

In the globalized world, learning democratic political knowledge is becoming an important element and also a tool for establishing effective relations and interaction with the people of as many countries as possible. Learning and understanding differences in political attitudes and political cultures would lead to the establishment of more friendly and constructive relationship and also to fuller social and economic engagement. For example, economic significance of tourism is huge today, both for the global economy and for individual economies. Tourism also has its huge impact on the relationship between economic, social, cultural and political lives (Sriupayo, 2016).

University students usually have enough time to follow the political events of many countries, depending on their interests, to collect the data on the political news worldwide, and to report them later in front of the whole class. In such a way we can study the degree of students' exposure to media and also to political socialization through media. And also, we can easily track how information is formed from an idea, then formed into knowledge, and then - if applicable, it turns into political wisdom and political understanding. Indirectly, we can also track what factors set the political agenda among the youth; which influences cultivate political beliefs and thus contribute to the development of country's political life.

Media exposure as one of the communication behavior patterns consists of 4 patterns. These are: media exposure itself, communication processes, motivational gratifications, and media credibility and preferences (McLeod \& O'Keefe, 1972).

Becker (1983) defines media exposure as the information exposure through: information search, information receptivity, and experience receptivity.

Almond \& Verba (1972) suggested that political information or political knowledge are appearing within political systems in the following order: input, process, output, feedback, and environment.

Political systems have general object within their structure (history, geography, political institutes and organizations etc.), the input of political objects (political party, bureaucracy, benefit group, member of parliament, media system etc.), the output of political objects (parliament, court, bureaucracy etc.), and the political self of the objects (personal roles in political life, self-evaluation in politics etc).

\section{Methodology}

This research is aimed at studying the factors affecting democratic political attitudes through analyzing the mass media in 3 categories: newspaperzs, television and radio. We considers the behavior in terms of media exposure on political issues of the university students, taking into account 5 variables: sex, age, field of study, academic level, and birth place.

A questionnaire was constructed and administered to university students at Suan Sunandha Rajabhat University, College of Innovation and Management. The total number of students in our sample was 126 . The multi-stage random sampling procedure was followed by a questionnaiery with application of the Likert five-point scales as the tool used for data collection. The analysis is based on the use of statistical methods, in particular, we were operating such notions as frequency, percentage and chi-square test at the significant level = 0.05 . 


\section{Results}

The research project was initially titled "The relationship between the behavior on media exposure in political issues and the democratic attitude of university students" is as table bellows.

Table 1 - Demographic data of the survey (made by the author)

\begin{tabular}{|c|c|c|c|}
\hline Item & Category & Number & Percentage \\
\hline \multirow[t]{2}{*}{ Sex } & Male & 45 & 35.7 \\
\hline & Female & 81 & 64.3 \\
\hline \multirow[t]{2}{*}{ Age (years) } & $\leq 20$ years & 74 & 58.7 \\
\hline & $>20$ years & 52 & 41.3 \\
\hline \multirow[t]{2}{*}{ Field Study } & Political Science & 34 & 27.0 \\
\hline & $\begin{array}{l}\text { Non-Political } \\
\text { Science }\end{array}$ & 92 & 73.0 \\
\hline \multirow{2}{*}{$\begin{array}{c}\text { Academic } \\
\text { Level }\end{array}$} & Year 1 (Freshy) & 48 & 38.1 \\
\hline & Other (Non-freshy) & 78 & 61.9 \\
\hline \multirow[t]{2}{*}{ Birth Place } & Bangkok & 52 & 41.3 \\
\hline & $\begin{array}{c}\text { Other (Non- } \\
\text { Bangkok) }\end{array}$ & 74 & 58.7 \\
\hline
\end{tabular}

In conclusion, the university is one of important institutions of society. The economic, societal and political factors in globalization play a significance role and influence the attitude of university students. The media as television, radio and newspapers educates university students outside of university as well as in university. The political socialization by media exposure is the cause of democratic political attitude. The university students could learn the political issues by viewing the television, reading the newspaper, and listening to the radio in the dimensions of time spent on political issues and frequency of use of political content categories.

Table 2 - Behavior of media exposure in political issues

(made by the author)

\begin{tabular}{|l|c|c|c|c|c|c|}
\hline \multirow{4}{*}{\begin{tabular}{l} 
Type of \\
Mass \\
\cline { 2 - 7 } Media
\end{tabular}} & \multicolumn{6}{|c|}{ Hehavior of media exposure in political issues } \\
\cline { 2 - 7 } & $\begin{array}{c}\text { Number } \\
\text { (persons) }\end{array}$ & $\begin{array}{c}\text { Percenta } \\
\text { ge }\end{array}$ & $\begin{array}{c}\text { Number } \\
\text { (persons) }\end{array}$ & $\begin{array}{c}\text { Percenta } \\
\text { ge }\end{array}$ & $\begin{array}{c}\text { Numbe } \\
\text { (2-4 days } \\
\text { (person } \\
\text { s) }\end{array}$ & $\begin{array}{c}\text { Percenta } \\
\text { ge }\end{array}$ \\
\hline Newspaper & 19 & 15.1 & 86 & 68.2 & 21 & 16.7 \\
\hline Television & 67 & 53.2 & 41 & 32.5 & 18 & 14.3 \\
\hline Radio & 30 & 23.8 & 11 & 8.7 & 85 & 67.5 \\
\hline
\end{tabular}




\section{MEDIA EXPOSURE BEHAVIOR ON POLITICAL}

The result of the behavior of media exposure in political issues from 3 categories: newspaper, television, and radio as shown in the Tab. 2.

The review research could set the tool with the questionnaire for finding the factors that affected democratic political attitude of university students.

The democratic political attitude of sample group classified by the score of three democratic political attitude: high score (51-62 scores), medium score (43-50 scores) and low scores (32-42 scores) which shown in Table 3.

The hypothesis testing in 3 relationships between the behavior of media exposure in political issues (newspaper, television, and radio) and the democratic political attitude are shown in the table respectively.

Table 3 - Democratic political attitude of sample group (made by the author)

\begin{tabular}{|c|c|c|}
\hline $\begin{array}{c}\text { Democratic Political } \\
\text { Attitude }\end{array}$ & Number (persons) & Percentage \\
\hline High score (51-62 scores) & 38 & 30.2 \\
\hline $\begin{array}{c}\text { Medium score (43-50 } \\
\text { scores) }\end{array}$ & 49 & 38.9 \\
\hline Low score (32-42 cores) & 39 & 30.9 \\
\hline
\end{tabular}

Table 4 - Relationship between the behavior regarding media exposure on political issues and the democratic political attitude of university students (constructed by the autor)

\begin{tabular}{|l|c|c|c|c|}
\hline \multicolumn{1}{|c|}{$\begin{array}{c}\text { Behavior regading media } \\
\text { exposure on } \\
\text { political issues }\end{array}$} & $\begin{array}{c}\text { High score } \\
(51-62 \\
\text { points })\end{array}$ & $\begin{array}{c}\text { Medium } \\
\text { score } \\
\text { (43-50 } \\
\text { points })\end{array}$ & $\begin{array}{c}\text { Low score } \\
(32-42 \\
\text { points) }\end{array}$ & $\begin{array}{c}\text { Total } \\
\text { (persons) }\end{array}$ \\
\cline { 2 - 5 } & 6 & 2 & 11 & 19 \\
\hline $\begin{array}{l}\text { High level of engagement } \\
\text { (5-7 days per week) }\end{array}$ & 10 & 17 & 15 & 86 \\
\hline $\begin{array}{l}\text { Medium level (2-4 days } \\
\text { per week) }\end{array}$ & 22 & 30 & 13 & 21 \\
\hline $\begin{array}{l}\text { Low level (0-1 day per } \\
\text { week) }\end{array}$ & 38 & 49 & 39 & 126 \\
\hline Total (persons) & 14 & 25 & 28 & 67 \\
\hline $\begin{array}{l}\text { High level of engagement } \\
\text { (5-7 days per week) }\end{array}$ & 38 & 49 & 39 & 126 \\
\hline $\begin{array}{l}\text { Medium level (2-4 days } \\
\text { per week) }\end{array}$ & 21 & 15 & 5 & 41 \\
\hline $\begin{array}{l}\text { Low level (0-1 day per } \\
\text { week) }\end{array}$ & 3 & 9 & 6 & 18 \\
\hline Total (persons) & & & \\
\hline
\end{tabular}




\begin{tabular}{|l|c|c|c|c|}
\hline & \multicolumn{3}{|c|}{ Radio } & 30 \\
\hline $\begin{array}{l}\text { High level of engagement } \\
\text { (5-7 days per week) }\end{array}$ & 1 & 10 & 19 & 11 \\
\hline $\begin{array}{l}\text { Medium level (2-4 days } \\
\text { per week) }\end{array}$ & 1 & 3 & 7 & 85 \\
\hline $\begin{array}{l}\text { Low level (0-1 day per } \\
\text { week) }\end{array}$ & 36 & 36 & 13 & 126 \\
\hline Total (persons) & 38 & 49 & 39 & \\
\hline
\end{tabular}

Chi-square $=34.54$.

\section{Conclusions and Discussion}

The study produced the following findings:

1. University students with different fields of studies and different academic levels tend to have different behavior when it comes to media exposure regarding political issues from television only. Another 3 variables under study (sex, age, and birthplace) failt to demonstrate any significant relationship with the democratic political attitude. Meanwhile, all 5 variables (sex, age, field of study, academic level, and birthplace) did not appear to have any sort of relationship with the behavior when it comes to media exposure on political issues from the side of newspapers and radio.

2. University students with different fields of study and different academic level tend to have differences in their democratic political attitudes. The political science students and those with higher academic level demonstrate a different trend of political attitude then other study fields and/or first-year university students.

3. Overall, we can state that the behavior of university students regarding their media exposure on political issues from newspapers, television and radio has a certain relationship with the formation of their democratic political attitudes.

In conclusion we can state the following:

Popular media sources such as television, radio and newspapers educate university students both inside and outside the university. Own political beliefs on each political issue make university studen informationts search for more information supporting their ideas, and this indirectly contributes to advanced learning.

The study tool used in this questionnaire above can be also used in a different context for finding the relationship between the behavior regarding media exposure to political issues and the democratic political attitudes among university students.

\section{Suggestions}

The results presented demonstrate, first of all, that such variables as field of studies and academic level are the key influencing factors when it comes to democratic political attitude among university students in Thailand. In order to plan further democratic development which would surely involve today's university students in the course of their political socialization, extra efforts should be dedicated to the development and strengthening of the related social institutions and their operations under democratic regime. 


\section{MEDIA EXPOSURE BEHAVIOR ON POLITICAL}

\section{Acknowledgement}

The author would like to thank the Faculty of Humanities and Social Science, College of Innovation and Management, Suan Sunandha Rajabhat University (www.ssru.ac.th), Bangkok, Thailand for the financial support.

\section{References}

Almond, G. A. \& Verba, S. (1972). The Civic Culture: Political Attitudes and Democracy in Five Nations. New Jersey: Princeton University Press.

Becker, S. L. (1983). Discovering Mass Communication. Illinois: Scott, Foresman and Company.

Hargreaves, A. (2003). Teaching in the Knowledge Society: Education in the Age of Insecurity. Philadelphia. Open University Press.

Mcleod, J, M. \& O'Keefe, G. J. (1972). The Socialization Perspective and Communication Behavior. In: Female, F.G. \& Tichenor, P.J. (eds.). Current Perspectives in Mass Communication Research. London: Sage Publications.

Mills, H. (2000). Artful Persuasion: how to command attention, change minds, and influence people. New York: AMA Publications.

O’Neil, P. H. (2015). Essentials of Comparative Politics (5th ed.). New York: W.W. Norton \& Company, Inc.

Payne, R. J. (2009). Global Issues: Politics, Economics, and Culture. New York: Pearson Education.

Pye, L. W. (1963). Politics, Personality and Nation Building: Burma's Search for Identity. New York: Yale University Press.

Siribanpitak, P. (2009). Management and Provision of Education for a Small Planet. Bangkok: Prixwarn Graphic.

Sriupayo, S. (2016). The Climate Change and Impact of Marine Tourism - A Case Study: Phuket, Thailand. Faculty of Humanities and Social Science, Suan Sunandha Rajabaht University, Thailand.

Paper submitted

Paper accepted for publishing

Paper published online
06 December 2017

21 February 2018

30 March 2018 